\title{
Use of dressing with human fibrin and thrombin during resection of a right atrial angiosarcoma
}

\author{
Grzegorz Filip ${ }^{1}$, Maciej Bochenek ${ }^{1}$, Bogusław Kapelak ${ }^{1}$ Krzysztof Bartuśs ${ }^{1}$, Małgorzata Urbańczyk ${ }^{2}$, \\ Jerzy Sadowski ${ }^{1}$ \\ ${ }^{1}$ John Paul II Krakow Specialist Hospital, Clinical Department of Cardiovascular Surgery and Transplantation, Krakow, Poland \\ 2John Paul II Krakow Specialist Hospital, Department of Rapid Diagnostics, Krakow, Poland
}

Kardiochirurgia i Torakochirurgia Polska 2015; 12 (2): 150-152

\begin{abstract}
Primary malignant cardiac tumors are rare and are usually detected at an advanced stage of disease. Their location and infiltration often hinder surgical resection. Tissue sarcomas, especially angiosarcomas, are composed of irregular and delicate vascular tissue. The resection of such tumors from the heart is associated with a high risk of life-threatening bleeding that cannot be stopped with traditional surgical methods. We present a case report of the application of a dressing containing human fibrin and thrombin in order to prevent bleeding during the partial resection of advanced cardiac angiosarcoma in a 40-year-old patient.
\end{abstract}

Key words: angiosarcoma, TachoSil, bleeding.

\section{Introduction}

Primary cardiac tumors constitute a rare and dangerous group of diseases. A decided majority of such tumors, i.e. $75 \%$, are benign [1]. The most common primary cardiac tumor is myxoma - a benign neoplasm usually located in the left atrium. The most common malignant cardiac tumor is angiosarcoma, which can usually be found in the right atrium [2]. Due to scarce symptoms, the tumors are often diagnosed only after they metastasize. The prognosis for patients with such tumors is typically unfavorable [3]. The treatment consists in surgical resection supplemented with chemotherapy [4]. The factors which impede complete tumor removal include tumor location and growth causing infiltration of the right ventricle, the tricuspid valve, and the right coronary artery [5]. The tumor's morphological structure inhibits proper hemostasis during procedures.

\section{Streszczenie}

Pierwotne złośliwe nowotwory serca występują rzadko i zwykle są wykrywane w zawansowanym stadium choroby. Ich lokalizacja i naciekanie często uniemożliwiają pełną chirurgiczną resekcję. Tkanki mięsaków, a w szczególności naczyniakomięsaka, zbudowane są z nieregularnej i delikatnej tkanki naczyniowej. Podczas usuwania takich guzów z serca istnieje duże ryzyko wystąpienia groźnego krwawienia niedającego się zaopatrzyć tradycyjnymi metodami chirurgicznymi. W pracy przedstawiono zastosowanie opatrunku zawierającego ludzką fibrynę i trombinę w celu zapobieżenia krwawieniu podczas operacji częściowej resekcji zaawansowanego naczyniakomięsaka z serca 40-letniej pacjentki.

Słowa kluczowe: naczyniakomięsak, TachoSil, krwawienie.

\section{Case study}

The 40-year-old female patient was referred to the clinic with the diagnosis of a right atrial tumor. One month before, during a routine gynecological examination, the patient was diagnosed with a uterine tumor. After preliminary diagnostics, the patient underwent hysterectomy with adnexectomy. Based on the histopathological examination of the removed material, angiosarcoma was diagnosed. Control abdominal ultrasonography revealed a tumor focus in the liver, while echocardiography revealed a tumor in the right atrium. Two days after the procedure, the patient was admitted to the Clinic of Cardiac Surgery to undergo heart surgery. Echocardiography performed at admission revealed a tumor in the right atrioventricular furrow $43 \times$ $20 \times 18 \mathrm{~mm}$ in size, infiltration of the right atrium and right ventricle with possible involvement of the right coronary artery, and fluid in the pericardial sac. Further preopera- 


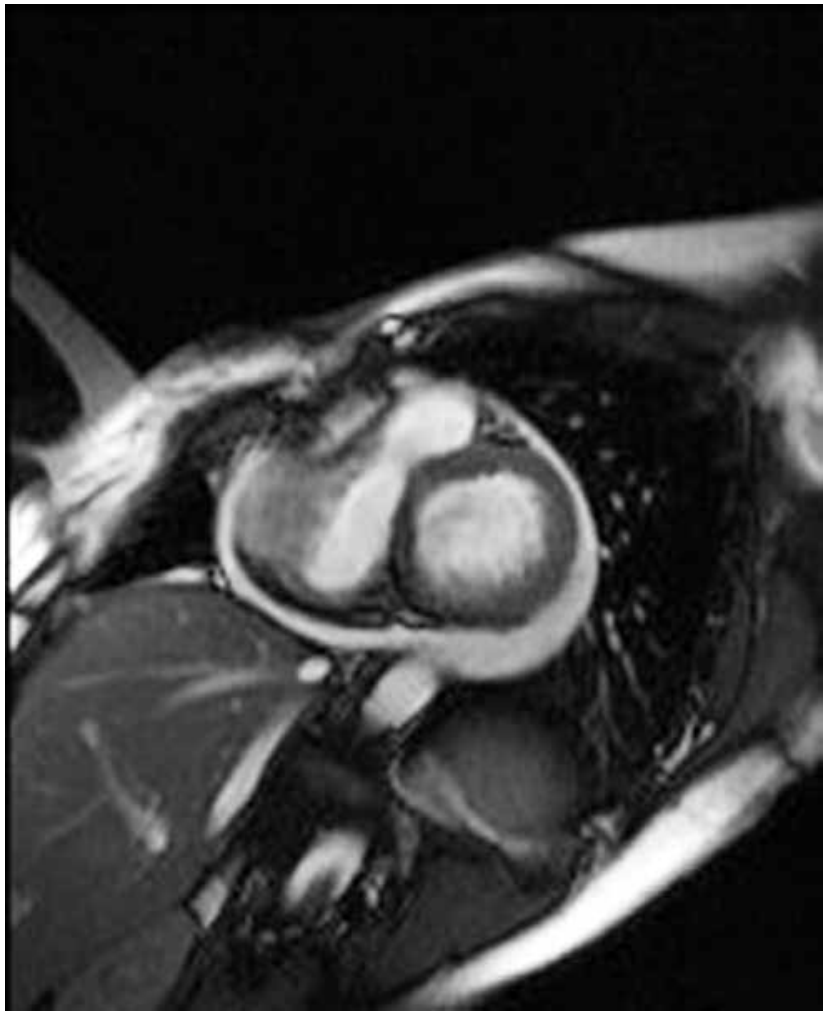

Fig. 1. Magnetic resonance of the heart

tive diagnostics included magnetic resonance of the heart, which revealed a right atrial tumor involving the atrial wall, infiltrating around the right coronary artery, and herniating into the lumen of the right atrium, as well as fluid in the pericardium (Fig. 1).

The procedure was performed via median sternotomy, in normothermia, with the use of extracorporeal circulation. After the pericardial sac was incised, the pressure pushed out $300 \mathrm{ml}$ of bloody fluid. The opening of the pericardial sac visualized a large tumor growing out of the right atrial wall (Fig. 2).

In order to stop and protect the myocardium, a cold crystalloid cardioplegic solution was used. A substantial portion of the tumor was removed from the right atrium. A fragment of the lesion, approx. $10 \times 20 \mathrm{~mm}$ in size, was left in the vicinity of the right coronary artery due to the infiltration of the coronary artery and the right atrium. The resected tumor fragment had the structure of cavitary vessels filled with blood. The remaining margins were coagulated with an electric knife. The defect of the atrial wall was reconstructed with a fragment of the pericardial sac $5 \times 5 \mathrm{~cm}$ in size. A pericardial patch was sutured onto the resected tumor fragment to prevent bleeding. Despite the use of 4.0 sutures and Teflon patches, the prevention of bleeding was not successful due to the delicate structure of the neoplastic tissue. In order to stop further bleeding, a $4.8 \times 4.8 \mathrm{~cm}$ dressing covered with human blood coagulation factors (TachoSil, manufactured by the Swiss company Nycomed) was placed on the resected fragment of the tumor (Fig. 3). The activation of coagulation factors on the dressing required delicate compression over sev-

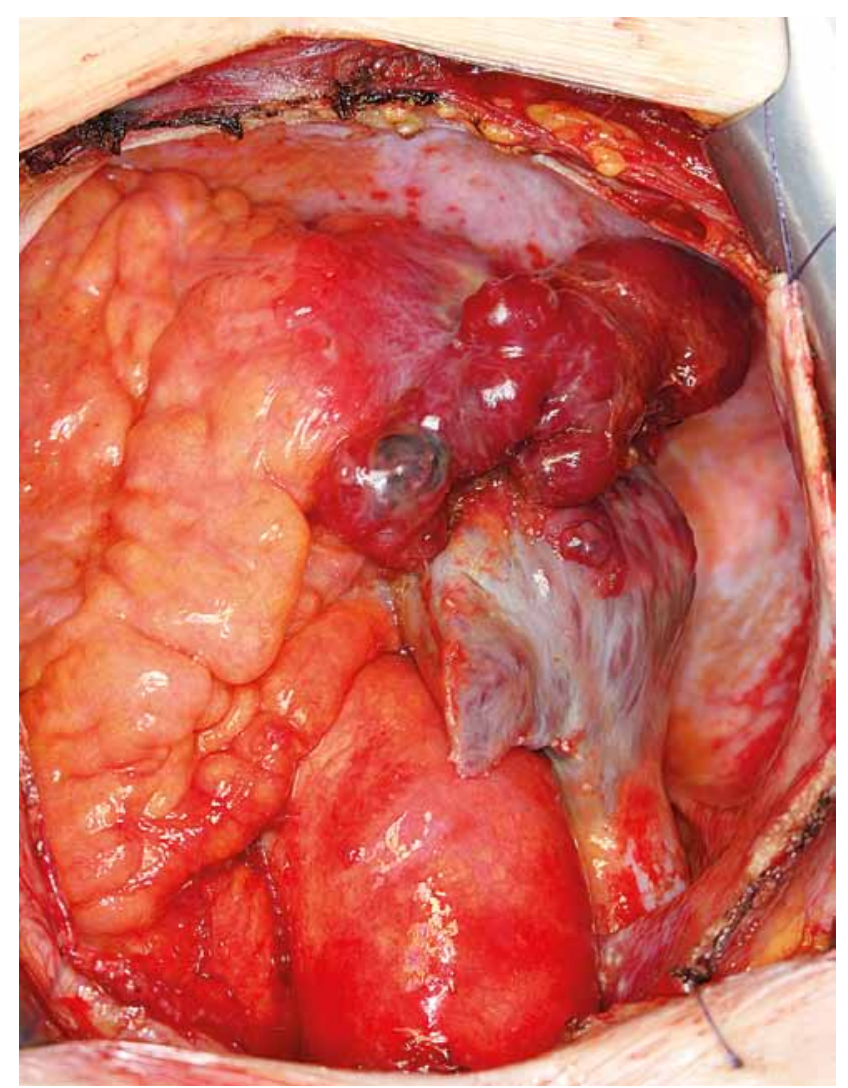

Fig. 2. Perioperative image
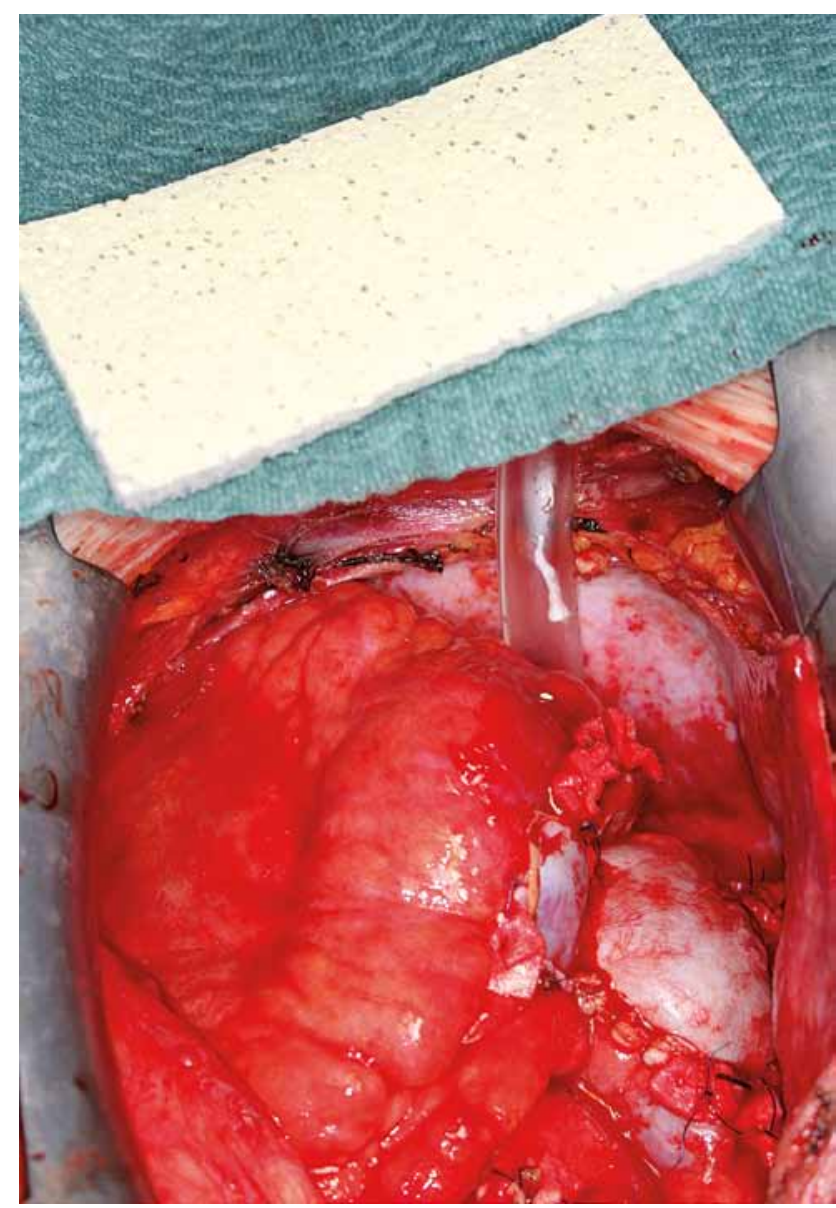

Fig. 3. TachoSil dressing 
eral minutes. Hemostasis monitoring revealed that another fragment of the tumor remained unsecured, and another Tachosil dressing $(3 \times 2.5 \mathrm{~cm}$ in size) was placed over this fragment. The rest of the procedure was uneventful. The removed tumor fragment was sent for histopathological examination. The patient was extubated 7 hours after the surgery. The chest drains were removed on the $2^{\text {nd }}$ postoperative day. Total drainage amounted to $460 \mathrm{ml}$. Control cardiac echo performed before discharge revealed a small amount of fluid in the pericardial sac with no signs of compression, considerable saturation of the right atrial wall, and contractility disorders of the right ventricle. The patient was discharged on the 6th postoperative day. Histopathological examination revealed the same histological type of the removed tumor fragment as in the uterus - angiosarcoma. The patient was referred for chemotherapy. After ten cycles of therapy, the mass of the tumor was reduced. The patient went back to work, but remains under oncological supervision. The duration of follow-up is 6 months.

\section{Discussion}

The late detection of the neoplastic lesions precluded a complete resection of the tumor from the myocardium. If the resected tumor mass had not been secured correctly, the patient would have faced the risk of a dangerous hemorrhage and cardiac tamponade. The delicate structure of the tumor precluded the provision of efficient hemostasis with traditional surgical methods. The use of TachoSil ensured effective and durable hemostasis.
TachoSil consists of a biodegradable sponge covered with human fibrinogen and thrombin. When they come in contact with the patient's blood, these substances form a fibrin network which makes the sponge adhere to the bleeding surface. The dressing has found a wide spectrum of applications in many fields of general surgery (inhibiting bleeding from parenchymal organs), thoracic surgery (preventing not only bleeding, but also pleural adhesions and air leaks), and cardiac surgery [6, 7].

Based on our observations, TachoSil may be used to control the hemostasis of delicate vascular structures that cannot be removed completely.

\section{Disclosure}

Authors report no conflict of interest.

\section{References}

1. Silverman NA. Primary cardiac tumors. Ann Surg 1980; 191: 127-138.

2. Roberts WC. Primary and secondary neoplasms of the heart. Am J Cardiol 1997; 80: 671-682.

3. Putnam JB Jr, Sweeney MS, Colon R, Lanza LA, Frazier OH, Cooley DA. Primary cardiac sarcomas Ann Thorac Surg 1991; 51: 906-910.

4. Bear PA, Moodie DS. Malignant primary cardiac tumors: The Cleveland Clinic experience, 1956-1986. Chest 1987; 92: 860-862.

5. Cohn LH. Cardiac Surgery in the Adult. McGraw-Hill, New York 2008.

6. Joseph T, Adeosun A, Paes T, Bahal V. Randomised controlled trial to evaluate the efficacy of TachoComb $\mathrm{H}$ patches in controlling PTFE suture-hole bleeding. Eur J Vasc Endovasc Surg 2004; 27: 549-552.

7. Maisano F, Kjaergård HK, Bauernschmitt R, Pavie A, Rábago G, Laskar M, Marstein JP, Falk V. TachoSil surgical patch versus conventional haemostatic fleece material for control of bleeding in cardiovascular surgery: a randomised controlled trial. Eur J Cardiothorac Surg 2009; 36: 708-714. 